\title{
Analysis of the Utilization of FDI in Yunnan Province
}

\author{
Wand Yueshi* \\ International Business School \\ Yunnan University of Finance and Economics \\ Kunming, China \\ 15172521779@163.com
}

\author{
Nie Fangmeng \\ International Business School \\ Yunnan University of Finance and Economics \\ Kunming, China \\ 645578024@qq.com
}

\begin{abstract}
The aim of this paper is to put forward some suggestions on how to make use of FDI in Yunnan Province. There are three parts in this paper. First, it introduces the situation of the use of FDI in Yunnan Province. Then, the relationship between FDI and GDP in Yunnan province is analyzed, It is found that FDI has a positive effect on the growth of GDP. Third, it gives some suggestions on how to improve the utilization of FDI in Yunnan province.
\end{abstract}

\section{Keywords-FDI; GDP; Yunnan province}

\section{INTRODUCTION}

FDI has been a hot research topic in the world since 1980s. Almost all developing countries and regions are committed to attract foreign direct investment. Along with the implementation of China's "The Belt and Road Initiatives" strategy, the introduction of FDI seems to have a new opportunity. Yunnan Province is located in the southwest border areas. In terms of geographic location and economic status, Yunnan Provinceare is closely related to the implementation of "The Belt and Road Initiatives" strategy. In this case, wether FDI could accelerate the development of economy in Yunnan Province?

\section{The Situation OF FDI IN YunNan PROVINCE}

In 2014, there are 132 foreign investment projects in Yunnan Province, increasing by $13.79 \%$ over last year.The utilized contracted foreign investment of the projects was $\$$ 1.08 billion, decreasing by $10.87 \%$ over last year. The actual use of foreign capital is $\$ 2.7$ billion, increasing by $7.60 \%$ over last year [1].

\section{A. Analysis of the Utilization of FDI in Yunnan Province (Industry)}

As shown in Table 1, according to agreement payment amount in 2014, the top three of the industry are: Manufacturing, Real Estate and Services. According to the actual use of the amount, the top three of the industry are:Real Estate, Manufacturing and Services. The largest amount of actual use in the industry is Real Estate.
TABLE I. The UtiLIZATION OF FDI By SECTOR (2014)

(USD 100 million)

\begin{tabular}{|c|c|c|}
\hline National Economic Sector & $\begin{array}{c}\text { Contracted } \\
\text { Investment } \\
\text { Amount } \\
\end{array}$ & $\begin{array}{c}\text { Actual } \\
\text { Investment } \\
\text { Amount } \\
\end{array}$ \\
\hline Yunnan & 10.82 & 27.06 \\
\hline $\begin{array}{l}\text { Farming,Forestry,Animal Husbandry } \\
\text { and Fishery }\end{array}$ & 0.26 & 0.21 \\
\hline Mining and Quarrying & 0.31 & 0.49 \\
\hline Manufacturing & 3.46 & 7.84 \\
\hline $\begin{array}{l}\text { Production and Supply of } \\
\text { Electricity, Gas and Water }\end{array}$ & 1.42 & 1.63 \\
\hline Construction & 0.54 & 0.92 \\
\hline $\begin{array}{l}\text { Geological Prospecting and Water } \\
\text { Conservancy }\end{array}$ & 0.00 & 0.00 \\
\hline $\begin{array}{l}\text { Transport,Storage,Postal and } \\
\text { Telecommunication Services }\end{array}$ & 0.05 & 0.00 \\
\hline $\begin{array}{c}\text { Wholesale and Retail Trade and Food } \\
\text { Services }\end{array}$ & 1.32 & 1.29 \\
\hline Real Estate & 2.06 & 9.46 \\
\hline Services & 1.45 & 5.22 \\
\hline Health Care,Sports and Social Welfare & 0.00 & 0.00 \\
\hline $\begin{array}{c}\text { Education,Culture and } \\
\text { Arts,Broadcasting,Film and Television }\end{array}$ & 0.00 & 0.00 \\
\hline $\begin{array}{l}\text { Scientific Research and Polytechnic } \\
\text { Services }\end{array}$ & 0.00 & 0.00 \\
\hline Others & 0.00 & 0.00 \\
\hline
\end{tabular}

Data source: Statistical Yearbook of Yunnan Province (2015)

B. Analysis of the Utilization of FDI in Yunnan Province (Region)

As shown in Table 2, according to different regions, by compare with FDI in Yunnan Province between 2013 and 2014 , we found that the amount of investment in each region is not the same, the growth rate is also different.

The top five are: $103.13 \%$ increase in Lincang, $87.5 \%$ increase in Honghe, $47.62 \%$ increase in Dali, $30.77 \%$ increase in Kunming and $25.35 \%$ increase in Qujing. The largest amount of FDI in Kunming, it was \$ 2.044 billion.

\footnotetext{
* Corresponding author
} 
TABLE II. The UtilizATION OF FDI By REgION (2014)

(USD 100 million)

\begin{tabular}{|c|c|c|c|}
\hline Region & $\begin{array}{l}\text { Investment } \\
\text { Value(2013) }\end{array}$ & $\begin{array}{l}\text { Investment } \\
\text { Value(2014) }\end{array}$ & amplitude \\
\hline Yunnan & $\mathbf{2 5 . 1 5}$ & $\mathbf{2 7 . 0 6}$ & $\mathbf{7 . 5 9 \%}$ \\
\hline Kunming & 15.63 & 20.44 & $30.77 \%$ \\
\hline Qujing & 0.71 & 0.89 & $25.35 \%$ \\
\hline Yuxi & 0.81 & 0.74 & $-0.09 \%$ \\
\hline Baoshan & 1.06 & 1.19 & $12.26 \%$ \\
\hline Zhaotong & 0.14 & 0 & $-100.00 \%$ \\
\hline Lijiang & 0.07 & 0.07 & $0.00 \%$ \\
\hline Pu'er & 0.79 & 0.69 & $-12.66 \%$ \\
\hline Lincang & 0.32 & 0.65 & $103.13 \%$ \\
\hline Chuxiong & 0.19 & 0.2 & $5.26 \%$ \\
\hline Honghe & 0.32 & 0.6 & $87.50 \%$ \\
\hline Wenshan & 0 & 0 & $0.00 \%$ \\
\hline Xishuangbanna & 0.09 & 0.04 & $-55.56 \%$ \\
\hline Dali & 0.63 & 0.93 & $47.62 \%$ \\
\hline Dehong & 1.04 & 0.26 & $-75.00 \%$ \\
\hline Nujiang & 0 & 0 & $0.00 \%$ \\
\hline Diqing & 0.65 & 0.3 & $-53.83 \%$ \\
\hline Those Directly under & 1.77 & 0.03 & $-98.30 \%$ \\
Provincal & \multicolumn{2}{|l}{} \\
Government & Data source: Statistical yearbook of Yunnan Province (2015) \\
\hline \multicolumn{3}{|l|l}{} \\
\hline
\end{tabular}

\section{EMPIRICAL ANALYSIS BETWEEN FDI AND GDP IN YUNNAN PROVINCE}

As discussed before, we have been analyzed the situation of utilizing foreign capital in Yunnan Province, and then we will try to find out the relationship between FDI and economic growth by regression analysis.

To measure a national / regional economic development level, the most intuitive indicator is gross domestic product (GDP). So select the data from 2001 to 2014, the data is about the number of FDI in Yunnan Province and the GDP in Yunnan Province.

Reasons for selecting data between 2001 to 2014 are as fellows. In the early years, the development level of China's market is still not good enough, low level of openness, economic development could not only rely on foreign investment, the main motive force of the economic growth is the government investment, FDI's role in economic growth is limited and easy to be influenced by politics.

With the reform of China's market, China's accession to the WTO and other factors, the degree of openness of Yunnan gradually increased, the amount of FDI steady growth every year, with a high degree of GDP growth. Therefore, the selection of the data of this period has a great significance.

Due to the sample size is too small, correlation analysis will be biased, but the purpose of this paper isn't in order to obtain a precise conclusion, and just want to draw an abstract concept, namely the use of FDI has been a role in promoting to economic growth, so as to provide theoretical support for behind the proposal.
TABLE III. The Amount of ForeIGN DiRECt InVESTMENT AND THE AMOUNT OF GDP IN YUNNAN PROVINCE

(RMB 100 million)

\begin{tabular}{|c|c|c|}
\hline Year & $\begin{array}{l}\text { Foreign Direct } \\
\text { Investment value }\end{array}$ & $\begin{array}{c}\text { GDP in Yunnan } \\
\text { Province }\end{array}$ \\
\hline 2001 & 5.30 & 2138.31 \\
\hline 2002 & 9.27 & 2312.82 \\
\hline 2003 & 13.91 & 2556.02 \\
\hline 2004 & 11.75 & 3081.91 \\
\hline 2005 & 15.48 & 3462.73 \\
\hline 2006 & 24.07 & 3988.14 \\
\hline 2007 & 30.04 & 4772.52 \\
\hline 2008 & 53.96 & 5692.12 \\
\hline 2009 & 62.16 & 6169.75 \\
\hline 2010 & 89.97 & 7224.18 \\
\hline 2011 & 112.25 & 8893.12 \\
\hline 2012 & 138.18 & 10309.47 \\
\hline 2013 & 155.45 & 11832.31 \\
\hline 2014 & 166.22 & 12814.59 \\
\hline
\end{tabular}

As shown in table three, between 2001-2014, the GDP and FDI of Yunnan province is increasing year by year, make a scatter diagram based on the data, as follows:

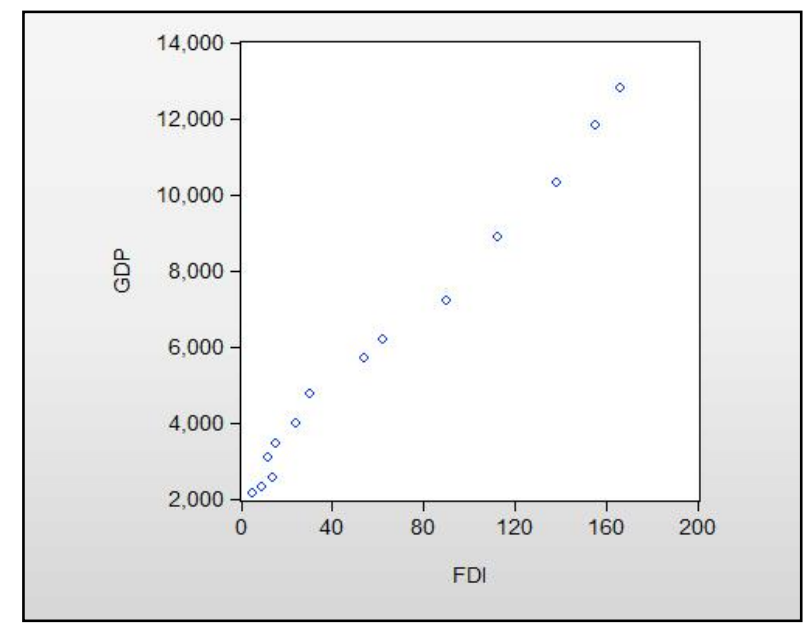

Fig. 1. The relational scatter diagram between FDI and GDP.

We can see that GDP and FDI meet the linear relationship, in order to make the coefficient easy to handle, obtain the logarithm of FDI and GDP. In addition, FDI have a lagging effect on the economic, it means that FDI in last year will have a effect on this year's GDP, so we can assume that, this year's GDP will be effected by FDI in last year. The models are described as follows:

$$
\operatorname{InGDP}_{\mathrm{t}}=\mathrm{C}+\alpha \text { In FDI }_{\mathrm{t}-1}+\mathrm{u}
$$

InGDP $_{t}$ is the natural logarithm of current GDP, InFDI $_{t-1}$ is the natural logarithm of the FDI in the last issue, $\mathrm{C}$ is a constant term, $\alpha$ is the Influence coefficient, $\mathrm{u}$ is the perturbation term. 
According to the data in table three, through the Eviews software, carries on the regression analysis, we obtained the following result:

TABLE IV. The Result of EviEWs Software

\begin{tabular}{|c|r|c|c|r|}
\hline Variable & Coefficient & $\begin{array}{c}\text { Std. } \\
\text { Error }\end{array}$ & t-Statistic & Prob. \\
\hline C & 7.178920 & 0.070952 & 101.1793 & 0.0000 \\
\hline LOG(FDI)-1 & 0.520691 & 0.024880 & 20.92779 & 0.0000 \\
\hline R-squared & 0.973332 & Mean dependent var & 8.545375 \\
\hline Adjusted R-squared & 0.971109 & S.D. dependent var & 0.611230 \\
\hline S.E. of regression & 0.103892 & Akaike info criterion & -1.559359 \\
\hline Sum squared resid & 0.129524 & Schwarz criterion & -1.468065 \\
\hline Log likelihood & 12.91551 & Hannan-Quinn criter & -1.567810 \\
\hline F-statistic & 437.9725 & Durbin-Watson stat & 1.403309 \\
\hline Prob(F-statistic) & 0.000000 & & \\
\hline By analyzing & & & \\
\hline
\end{tabular}

By analyzing the above results, the coefficient of perception is 0.973332 , the correction coefficient is 0.971109 , which shows that the goodness of the model. We come to a specific model:

$$
\operatorname{InGDP}_{\mathrm{t}}=7.178920+0.520691 \text { InFDI }_{\mathrm{t}-1}
$$

According to the model, we found that foreign direct investment in Yunnan province increased by $1 \%$ every year, and this year's GDP could increase by $0.520691 \%$. This result shows that foreign direct investment have a positive effect on GDP in Yunnan Province.

\section{SUGGESTIONS ON THE UTILIZATION OF FDI IN YUNNAN PROVINCE}

In the previous paper, we understand the basic situation of foreign direct investment in Yunnan Province, and through empirical analysis, it's confirmed that FDI have a positive effect on GDP in Yunnan Province. Next, I will put forward some suggestions on how to introduce foreign direct investment in Yunnan province.

\section{A. How to Direct the FDI}

The first industry is the dominant industry in Yunnan, but it doesn't play an important role. FDI mainly flows to the second industry in recent years, second industry will produce more pollution. Low investment in agriculture, high technology industry and service industry, leads to the use of foreign direct investment in Yunnan province isn't reasonable, seriously restrict the use of FDI in Yunnan Province, and poses a negative impact on the environment of Yunnan [2]. So,how to direct the FDI?
1) Optimizing the structure of foreign capital in the second industry. At present, the actual use of FDI in Yunnan Province, extensive and resource-based industries investment is still dominant, to invest in technology intensive enterprises is very little. Therefore, the government should encourage foreign investment to invest in the first industry and the third industry, at the same time, for this type of investment projects should be given tax incentives and financial support.

2) Strengthen policy guidance for the first and third industry investment. Yunnan as a famous tourism province, with rich resources, from the traditional planting to high-tech biological pharmaceutical industry have a unique development foundation. Because these industries usually have the characteristics of long payback period and high risk, often can not meet the purpose of foreign investors in the pursuit of short-term gains, which led to the difficult absorption of FDI in this industry. Therefore, the government should increase efforts to support this kind of industry, improve investment channels, reduce the administrative examination and approval procedures in these industries, to establish a complete service system.

\section{B. Improve the Soft Environment of FDI}

In order to guide actively the investment of foreign businessman, it is very important to enact the related decrees and laws. Market environment is a prerequisite to attract foreign direct investment. It determines the intensity of foreign direct investment. The soft environment of FDI, it is about an area of relevant policies and regulations, institutional mechanisms, government administrative capacity and the concept embodied in the process of economic development, and so on, it is the comprehensive performance of a regional soft power [3]. The soft environment of the foreign direct investment includes the system environment, the cultural environment, the service environment and the credit environment. Perfect soft environment has a strong appeal to foreign direct investment, the better the soft environment, the more production factors, the better resources allocation, the more favorable to economic development. For Yunnan Province, creating a better environment for foreign investment, have the following recommendations:

1) To create a legal environment to adapt to foreign direct investment. To improve the relevant laws and regulations, improve the patents and intellectual property rights protection system, forming good habits, so that the foreign direct investment enterprises can operate in law, and can enjoy the benefits of investment in Yunnan Province.

2) To create the atmosphere of opening up to the outside world. In the face of foreign direct investment with an open attitude, to provide the convenient conditions for foreign direct investment, promote cooperation with foreign direct investment, to create a favorable external environment for foreign direct investment.

3) The government should make efforts to attract foreign direct investment. Transformation of government functions, to create the rule of law government, service government, optimize the public service, improve the administrative capacity of the government. Strengthen the government credit construction, and create a credit system environment. The 
government should keep the credit, judicial fairness, tax justice, prevent policy changes, to create a stable, uniform policy environment for foreign direct investment, and enhance the transparency and stability of the policy. To strengthen the construction of financial market and improve the direct financing ability of foreign direct investment enterprises through the reform of financial system.

\section{ACKNOWLEDGMENT}

I would like to express my gratitude to all those who help me during the writing of this thesis. Any progress that I have made is the result of their profound concern and selfless devotion. Particularly, I am greatly indebted to my tutor, Professor Yin Hao. His willingness to give me his time so generously has been much appreciated. Truly, without his painstaking efforts in revising and polishing my drafts, the completion of this thesis would not have been possible.

Finally, I will carry forward the academic spirit, apply the knowledge to my career in the future, and return all people who care about me and return society.

\section{REFERENCES}

[1] T. Liu, "Study on the level of foreign capital utilization in Yunnan province," Yunnan University, 2015.

[2] J.F. Xu, "Research on the use of FDI and economic development in Yunnan province," Yunnan University of Finance and Economics, 2010.

[3] K. Yang, and J. Li, "Analysis of the structure and existing problems of foreign capital in Yunnan province," China's collective economy, 2013, pp. 11-12. 